\title{
JKAP
}

JKAP (Jurnal Kebijakan dan Administrasi Publik)

Vol.22 (2), November 2018, 117-127

ISSN 0852-9213 (Print), ISSN 2477-4693 (Online)

Available Online at https://journal.ugm.ac.id/jkap

\section{Communication and E-Government: The Case Study of E-Government Implementation in Tourism Communications in the Tourism Department, Daerah Istimewa Yogyakarta (DIY) Province}

\author{
Rosalia Prismarini Nurdiarti \\ Mercu Buana University \\ rosa@mercubuana-yogya.ac.id \\ Didik Haryadi Santoso \\ Mercu Buana University \\ didikharyadi.s@gmail.com
}

\begin{abstract}
The development of Digital Government Services (DGS) is a form of bureaucratic transformation. This research focuses on virtual digital technology used in the government, especially in the tourism office department of Yogyakarta special administrative region which is also known as Daerah Istimewa Yogyakarta (DIY) Province. Based on Ministry of Communication and Information (MoCI) 2012 report, e-Government adoption in DIY was ranked 4th in the country. The province has the vision of becoming a cyber province as one of the ways to fulfil the needs of its residents. The objectives of this study encompass: 1) description of the implementation of e-government in DIY Tourism department; 2) mapping and utilizing the tourism communication strategies to identify e-government implementation in the Tourism department; and 3) assess the role that e-government technology adoption can help to strengthen service encouraging the enhancement of service and creative industries towards contributing to improve the higher tourism development in DIY. The research used a case study approach with data collected using informal interview and documentation. Results of the research showed that: 1) the expertise in information and communication technology (ICT) is pivotal for was necessary for the development of ing the tourism-based websites and e-government applications; 2) the importance of developing multimedia-based content to ensure relevant and updated content; and 3) the importance of taking into account the needs and interests of undergraduates and undergraduate audience in developing and adoption of e-government services because they constitute the largest segment that uses the virtual digital government services
\end{abstract}

Keywords: e-government, implementation, information and communication, new media, technology 


\section{INTRODUCTION}

The advancement of communication technology does not only change the way to we communicate but also the how we o interact with others. Marshal McLuhan illustrates the concept of a 'global village' as the more receptive, inclusive worldwide, information society in the realm of government management, citizens, as one of the users of services, have become the rationale and priority of its functions and programs. The change that has impacted society, has also inevitably had its influence on government bureaucracy. The widespread and rapid internet technology access and use has been pivotal in creating new virtual networkbased communities, which business and government are using to deliver their products both effectively and efficiently, higher responsiveness and accountability.

The development of Digital Government Services (DGS) is one of bureaucratic transformations that has been facilitated by the adoption of information technology. Based on reliable sources, during 20112015 period, leading Digital Services in DIY Government included 11 sectors inter alia, (1) Labor and Transmigration; (2) Health; (3) Cooperation and Investment; (4) Education, Youth and Sports; (5) Culture; (6) Agriculture; (7) Spatial Planning and Regional Infrastructure; (8) Tourism; (9) Marine and Fisheries Affairs; (10) Transportation, Communication and Information; and (11) Industry, Trade, Cooperation and SMEs (Mrf, 2016).

It is evident in previous literature that research on e-government has often been taken the form of evaluation or comparison of the e-government implementation process at the local, district or city government levels Aspects that were the center of comparison in such studies have included infrastructure, public service processes, internet network support, software and hardware advancement, development of human resources, interaction, transactions, and connectivity fostered among various components of the government as well as attendant problems that emerged. Such aspects are considered crucial for an integrated egovernment system. What is also apparent in previous literature is the emphasis placed on the implementation of e-government in communication-based information services in other components of the governmental process. Thus, the development and adoption of e-government, was inherently intractable with the synergy among the mission, vision, authority, primary tasks and functions commitment, and responsibilities of each division. Previous literature has identified weaknesses in e-government adoption to include human resource inadequacy, insufficient funding to sustain e-government development and adoption in various institutions as well as over time, lack of transformational leadership, and interaction, transactions, and connectivity issues.

The focus of this study is on the impact that information resources, bureaucratic structure and funding on e-government implementation, with the focus placed on the assessing the extent to which egovernment in integrated into the tourism strategy of DIY Tourism Department. The contribution of this research to knowledge and practice on e-government development and adoption, lies in the important results on the influence that e-government adoption had had on the promotion and development of tourism services in DIY as a tourist and cultural destination for foreign tourists. The research did not only concentrate on the information and software development as such, but also the drivers that are discernible from , micro and local social, cultural, economic context that is referenced by, and serves as guidance in the creation of information and content as well as macro aspects that include bureaucratic structure and financial resources available to finance Tourism Department activities in DIY.

This limits its observation period on 2017-2018. Meanwhile, the choice of the research location, was based largely on several considerations that included, the fact that DIY is an important tourism destination Indonesia for both domestic and foreign tourists destination; DIY is one of the provinces in Indonesia that have implemented egovernment services; DIY recorded the highest number of foreign tourists (based on arrivals at Adisucipto airport during JanuaryJuly 2016; and Yogyakarta had the second 
highest hotel occupancy rates in Indonesia, second only to after Bali in July 2016. Data sources included the Central Bureau of Statistics (BPS) over the last few years, DIY province, which is renowned for its education, tourism and culture, has implemented various bureaucratic reforms, most notable of which being the development and adoption of e-government in the delivery of services. DIY is one of the provinces with a large number of internet users in Indonesia. Based on the data obtained from the Ministry of Communication and Information (MoCI), in 2012 e-government adoption in DIY ranked number four in Indonesia. The province has the mission of becoming a 'Cyber Province' which it expects to achieve by exploring and exploiting and taking advantage of strengths and opportunities, while at the same time, using various ways to mitigate and overcome weaknesses, challenges and threats. To achieve that vision, DIY hopes to leverage technological advancement in creating world-class quality human resource capacity. Since 2016, the province has implemented various activities and programs that are aimed at realizing the vision, including 'ICT-based Job Training Program', 'Computer Science Training', 'ICT Training and the Adoption of 21st- Century Learning Technology Concept', and use of e-reporting system (automatic reporting application for students that is currently used in over 50 schools).

While previous research focused on the provision of electronic web based services to serve online communities, the emphasis of this study was on the extent to which DIY had adopted e-government as part and parcel of its communications strategy for its policies and programs in the tourism department. Previous research on egovernment assessed the effectiveness of web based services that were implemented by municipalities. An example of such research was conducted by Aprilia, Wijaya, \& Suryadi (2014) on the effectiveness of egovernment services in Jombang district government. Results indicated that egovernment implementation had contributed to more effective interaction and delivery of electronic-based information. One of the problems the research identified was persistence in effectiveness of the interactive, transactional, and connectivity of the various stages. The implication, thus, is that egovernment implementation has yet to contribute to the creation of bidirectional and interactive communication between public service providers and users as well as among various district government offices and agencies in Jombang district.

In another research, Rachman (2015), analyzed e-government adoption in the delivery of public services in the Culture and Tourism Department, East Borneo Province. The focus of the research was on the role that human resources plays in the implementation of e-government. To that end, egovernment implementation in East Borneo among other initiatives encouraged government employees to use smart phones in conducing communications, facilitated employees education and training in workshops and multimedia exercises by relevant agencies. Results of the research showed that the existence of adequate human resources with relevant competences and skillsets was crucial for an effective e-government development and deployment. To that end, the lack of such human resource capacity in the provincial bureaucracy coupled with inadequate infrastructure, lack of sufficient hardware and software development, transparent and accountable public service process, were identified as obstacles that hampered egovernment. Communication strategy is a set of planned actions that are tailored to achieve certain goals through the use of communication models, techniques, and approaches. Communication is generally aimed at conveying message and information, with the objective of inducing change in behavior of those who are the recipients. To that end, the formulation of an effective communication strategy, which by and large, entails planning and management, demands into consideration conditions and circumstances that characterize the context.

The importance of communication in tourism cannot be overemphasized. Tourism, to a large extent depends much on the quality of communication that is used to depict tourist attractions, which in turn is influenced by the quality of the communication strategy employed, including but not limited to peer to peer communication, mass com- 
munication, and various forms of marketing and advertising (Bungin, 2015). Effective communication of tourism is important in conveying the value that potential tourists get when they visit tourist attractions, differentiating tourist destinations from competitors, accessibility issues, resources available to potential tourists and so on. The increasing advancement of information and communications technology, thus, will play an increasingly important role in the communications strategies that tourism departments use in implementing their outreach and general development programs and policies.

\section{METHOD}

The research uses an exploratory approach case study. The approach was used because of its ability to enable the research obtain a comprehensive and in depth picture of the research object, in this case egovernment adoption in the DIY tourism department. Another advantage of the case study approach, which Yin (2012) emphasized, which this research put to great use, was the assessment of not only the importance of communication in the implementation of e-government in DIY tourism department, but also the sub units that constitute the provincial office.

Data collection was based on interviews, observation, documentation, accessing archival records and relevant facilities. To allow as much opportunity for respondents to express their opinions and perspectives, open ended questions, hence not limited or confined by prior protocols (Yin, 2012) that provided sufficient room for exploration of issues. Observation technique was used because of its ability to enable the researcher pose as many questions as possible hence making good use of the knowledge of the respondents (Norman \& Yvona, 2000). That is possible thanks to the advantage of flexibility in framing ideas into reality of the observation technique.

Meanwhile, the documentation technique was used to collect data and information relating to previous studies, archived records and facilities on internet and various offline locations that were deemed relevant to the study. The research conducted direct observation of activities in DIY tourism of- fice with emphasis on the role of communication that played in the implementation of $e$ -government in the department. Thus, the research used several techniques to collect data to ensure that weakness in one technique were offset by strengths in other techniques, thereby contributing to higher data validity and consistence, and in turn, reliable study findings (Bungin, 2015).

\section{FINDINGS AND DISCUSSION}

To answer the research questions, the discussion below is divided into two literature review sections. The first section describes the communication technology discipline that contributes knowledge to the advancement of communication technology as a tourism marketing communication media. This field of study will develop along with the complexity of tourism communication. Some of the fields in question include: destination brand, online tourism communication, management tourism communication, and tourism visual communication (Bungin, 2015).

Secondly, the highlighted implementations were related to the human resources and advanced development stages such as interactions, transactional, and connectivity. Besides, the implementation concepts of Edward, Emerson, Grindle and Mize elaborate that the bureaucratic structure, funding, attitudes and commitment of program implementer, and information resources are the key to be successful in program implementation (Basofi, 2015).

This study was inspired by Edward et al conceptual framework that has been adapted to the research object and the gathered data. In the concept implementation perspective of Edward (1980), there are at least four dimensions of implementation: communication; information clarity; availability of human resources; 1) availability of information; 2) infrastructure; 3) funding; 4) attitudes and commitment of executors; and 5) bureaucratic structure.

This research uses several implementation concepts as illustrated in Figure 1. It can be seen that the availability of resources consists of human resources and information resources. While the infrastructure, funding, as well as bureaucratic structure are the next 
points. Specifically, the implementation of egovernment is associated with tourism communication strategy in Tourism Department of DIY.

\section{E-government in Tourism Communica- tion}

Based on the DIY government performance report (2015), DIY Tourism Department has the vision of "The realization of DIY as a leading cultural-based tourism destination in Southeast Asia, world class, competitive, sustainable, enable to encourage regional development for the welfare of the society". The vision, thus, underscores the goal of developing tourism in DIY to actualize and preserve the historical value of the region as a former capital city of this country along with its rich beautiful natural panorama.

The aforementioned vision highlights various cultural heritage sites such as temples, artifacts, palace (known as 'keraton'), and several buildings with unique architecture that are symbols of the greatness of the Javanese culture, preservation and valuable art, etc. In addition, various recreational facilities/ transportation infrastructure that support tourism services are also identified as important drivers of tourism strategy. From a cultural perspective, thus, tourism activities in DIY are portrayed as representation of Javanese culture attitude and behavior, which is rich in oriental and culture.

\section{Human Resources and Bureaucratic Structure of DIY Tourism Department}

E-government in DIY has, to a large extent, been based on improvements in the development of the virtual computer network technology and innovations. Improvement in virtual computer network technology has supported the development of a virtual communication system that meets the operational and managerial system needs of various institutions, including government activities. Government support for virtual network development and e-government programs, has also played a crucial role as role. Such support has taken the form of national legislation and in the form of presidential and ministerial regulations. Important as well has been the contribution of Universities in DIY which have established courses that are directly related to the development and utilization of information and communication technology.

Based on available data on human resources in DIY, the province lacks human resources with expertise in technology and information. This is reflected in the educational background of manpower in the tourism department, who are graduates of literature, tourism, and education. Even the few who have some knowledge and expertise on IT, acquisition of such expertise was through didactic methods. Recruiting human resources in DIY is the responsibility of Regional Human resources Board, and based on its sources, the agency has not appointed a single employee with specialization in Computer Science for all departments in DIY since 2000.

The implication of that is that in the event of technical problems that affect IT hardware and software and communication networks, technicians the department hires technicians to do the maintenance work.

"In 2014, only three employees in the Tourism Department had information technology specialization. This is because employees in the Tourism Department, are from educational backgrounds that are directly related to tourism. The implication of that is that manpower with specific competence in other areas that are not related directly to tourism is woefully inadequate, if at all any. In 2018, plans are underway to open recruitment for temporary workers who will be charged with organizing and maintaining networks. Today, the Department of Tourism has part time employees who are charged with planning and adoption of applications. Meanwhile, employees who work in Information section were drawn from Tourism Information Center (TIC), while those in TIC section are contract workers, whose service contracts are renewed every two years". (Interview with Don Charles, information Program, DIY Tourism Department, 7/9/2017).

As regards, the organizational structure, e-government program falls under the secretariat, of DIY Tourism Department. The secretariat is directly responsible to the head of the department, and oversees three areas, namely, general affairs, finance, programs, and information sub-departments. The head of the program and information sub-department is appointed by the head of DIY Tourism Department. Consequently, 


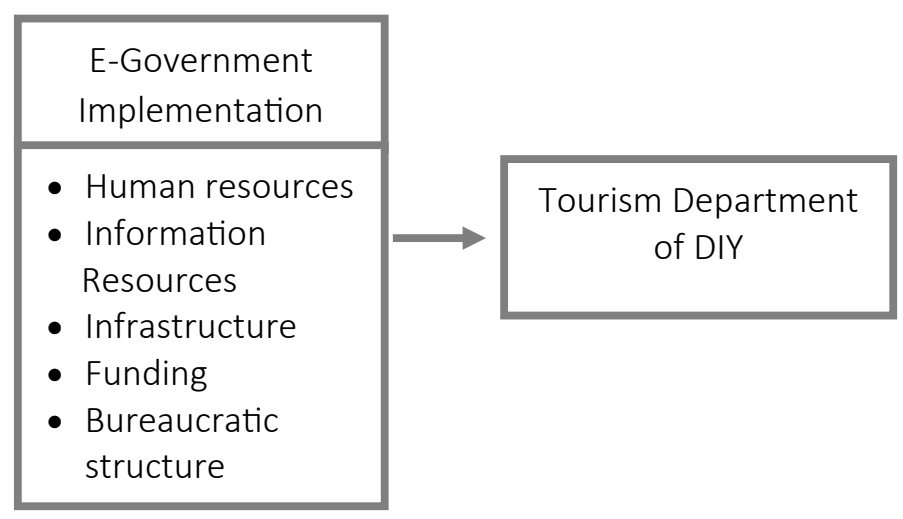

Figure 1. Research Model

the head of department is responsible for the performance evaluation of the programs and information sub department.. The Program and Information sub-department is charged with planning, monitoring and website maintenance. The division has five employees, who are not specialists in information technology field. The head of the program and information sub- department has tourism educational background, worked as a programmer staff since 2006 before he was appointed as the head of the program and information sub department.

The bureaucratic structure of the organization, the information and information technology sub- department used to be separate with its own budget and planning. Nonetheless, in 2010 the sub department was merged to become programs and information division. The consolidation was based on the Governor's Decree that vested the new division with planning and monitoring, maintaining data and websites, and statistical data reports. Performance evaluation is based on an online report system that the Governor delivers to relevant agencies. Meanwhile, performance appraisal is based on Employment Assessment Appraisal List (DP3) of civil servants, that among other aspects evaluates performance, discipline, cooperation, leadership, and duties performed in a year. In addition, employees undergo performance appraisal once in three months.

As regards, e-government implementation, the program and information division, conducted planning, statistical data monitor- ing, and website management. Planning activities related to website content development programs, tourism events, and financial planning, while monitoring of statistics related to tourist destinations, accommodation facilities, visitor attractions, tourism business, and supporting facilities and contribution of tourism to Local Own Revenue in DIY province. With respect to website management, activities involved updating of information periodically, website maintenance (both technically and layout) once every three months, and providing responses to some visitor comments as well as providing information on tourism. As regards human resource development, employees have an opportunity to undergo higher education by taking courses in basic training or computers, internet and network. Training is based on a circular sent by the regional human resources agency that selects at least two members of staff from IT division.

While centralized labor and human resource recruitment system has contributed to effectively meeting the needs of each subdivision in the department, the online report system that is used to evaluate employee performance being based on general tasks, does not specific competence needed for employees tasked with IT duties. There is thus need for recruiting employees who have competence in the information and technology. In any case, such a strategy is very much in line with long term strategy of transforming DIY into Jogja Cyber Province. The concept of world-class quality human resource, therefore, must be implement- 


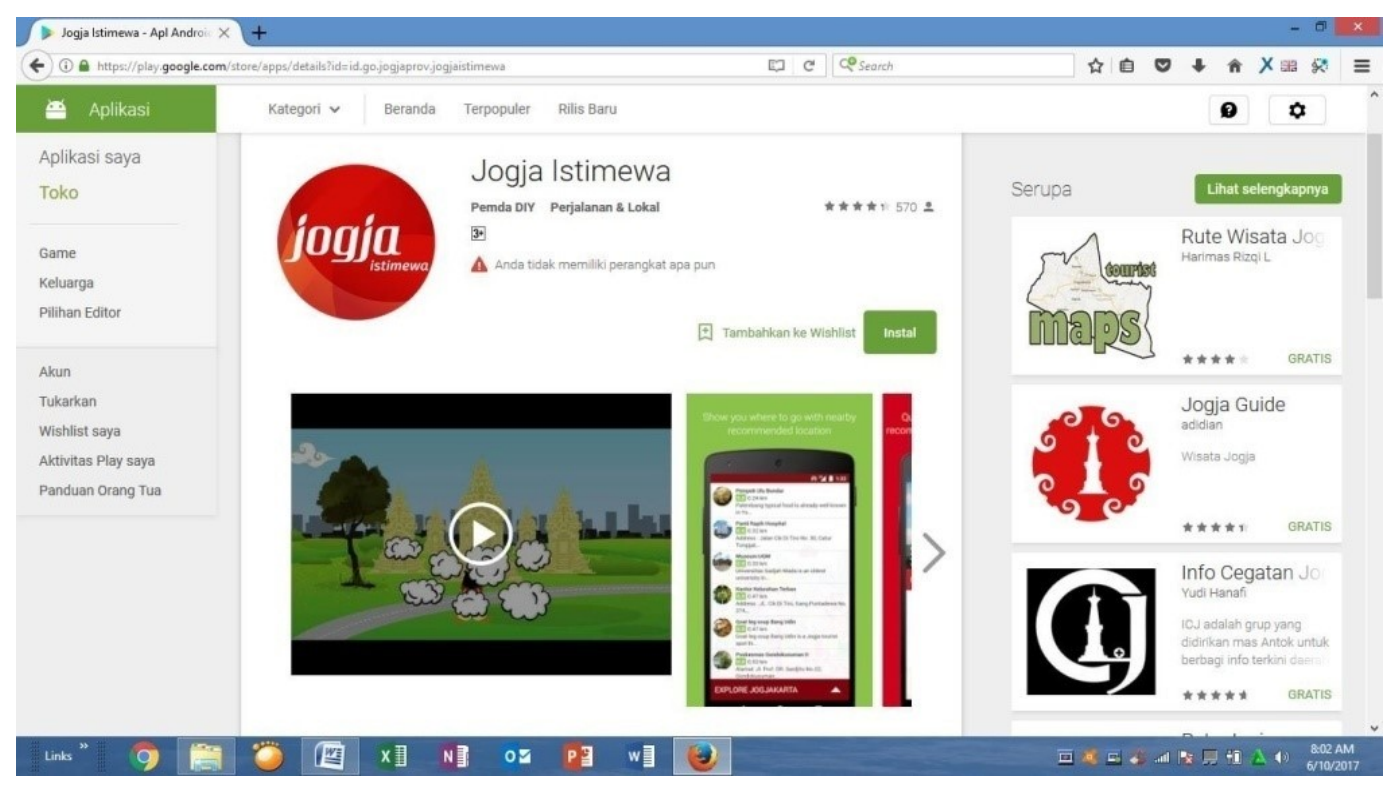

Figure 2. Jogja Istimewa application on mobile phone

Source : (https://play.google.com/store/apps/details?id=id.go.jogjaprov.jogjaistimewa )

ed at all levels, right from the district to the province, including various offices in DIY, one of which is the Tourism Department.

To that end, the implementation of egovernment development in DIY has been plagued by bureaucratic red tape, land procurement difficulties, absence of skilled manpower, and limited public participation. Specifically, limited public participation in e -government development has undermined collaboration and cooperation with stakeholders in the development of tourism in general, which in turn has adversely impacted on efforts to achieve goals and targets of the department, including e-government development (Wiloso, 2017).

\section{Infrastructure and Financing as Support- ing E-government Implementation}

E-government entails the development of electronic-based governance with the goal of improving the quality of public services effectiveness and efficiency. In this case, egovernment refers to the use of information technology and related products and services by governments, including intranets and the Internet, in delivering public services to the general public, businesses, as well as in conducting administrative duties that are related to tourism. Effective e-government development depends on the existence of an efficient IT infrastructure that has the ability to ac- commodate e-government applications and services that are run the tourism department in providing services to the community. To that end, the existence of an appropriated designed, deployed, maintained and managed is a sustainable standard IT infrastructure.

Based on information and observation of e-government implementation in the DIY tourism development, it is very apparent that IT infrastructure that supports e-government deployment and public interaction is already in place. This is reflected in the availability of personal computers that have adequate standard specifications to operate on internet networks. The hosting domains are availed by the Ministry of Communications and Information. Moreover, maintenance of e-government infrastructure is done regularly once a month. Thus, while some minor problems often arise such as glitches in computer software, internet disruptions that cause difficulties in uploading and publishing information on websites, the performance of e-government system is not generally fundamentally affected thanks to services of IT technicians DIY Tourism Department periodically hires to handle such problems whenever they arise. The department of tourism has in place a special room for information technology (IT), which hosts three servers and other related e-government IT 
hardware and supporting system. Nonetheless, all IT hardware and supporting equipment is under the management of one employee. As if that is not enough, software used in IT must be updated once every three months, which increases both work load, cost, and coordination with all units that are connected and using e-government services in the Tourism department. In addition, considering the wide range of services and connections to several divisions in the tourism department, there is little doubt that the existing IT infrastructure is also not optimal to delivery both administrative and public service related e-government services.

Cooperation with the Office of Communications and Information needs to be detailed in any aspect and the extent of the authority to support the DIY Tourism Department. With regards to funding, some of the financing used manage e-government comes from Fund Privileges (Danais), Local Government Budget (APBD) and Central government Budget (APBN). The distribution of source of funds is elucidated in the excerpt of an interview that follows.

\begin{abstract}
"The budgeting process that relates to e-government falls under the Program and Information sub-department, in the Tourism department. Funds come from the privileges fund, Danais, which ranges from Rp.10 Billion; APBD funds that ranges from Rp.30 Billion to Rp.32 Billion; and APBN (Ministry of Tourism) ranges from RP.7 Billion to 1.5 Billion. Financing website management, which is about 200 million rupiah per year comes from APBD budget. The outlay on website management includes portal, maintenance, honorarium and allowances paid for content input and management. Meanwhile, $A P B N$ funds come from the Ministry of Communications and Information (Kemenkominfo), while APBD and Danais funds are used to finance the conduct various tourism events.". (Interview with Don Charles, Program and information Department, Tourism Office of Yogyakarta, 7/9/2017)
\end{abstract}

\section{Information Resources for E-government in $D I Y$ Tourism Department}

$D I Y$ tourism development is based on DIY Regulation No. 1/ 2012 on DIY Tourism Development Master Plan (RIPPARDA), which also serves as the legal foundation for development of cultural tourism in $D I Y$. The launching of a new slogan, "Jogja Is- timewa", is expected to enhance the support and enthusiasm of all stakeholders of $D I Y$ tourism in contributing to the realization of the potential of DIY tourism. Thus, the special status of the region is expected to strengthen good governance, improvement in the management of tourist attraction, and the development of quality tourism industry. Achieving the above objectives will also contribute to the achievement of DIY2025 vision of becoming the leading tourist destination in Southeast Asia.

In fact, as one of the ways to achieve the vision, DIY Tourism Department website migrated has since 2005 migrated to www.visitingjogja.com, which was aimed at increasing the prominence of DIY as a destination for cultural and education tourism in Southeast Asia. The website is linked to a database that contains links to various tourist destinations, hotels, events, accommodations and other issues of tourism related information. As tourism development is an ongoing process, the website also has space for comments and aspirations of stakeholders (web visitors). Comments and opinions that come from website visitors serve as in puts on improving data collection and updating process, which is conducted by the program and information division with the collaboration of content providers, who are officer services based on contracts

E-government and tourism policy in DIY in general and the development and obtaining of content and information in particular, DIY tourism department, often makes use of opinions and advice from third party who include travel agencies, DIY tourism communities, bloggers and event organizers on one hand, and tourism departments in the five districts in $D I Y$ in the collaboration with the five districts, takes the form of data and information uploads that is done in each district government to the website. In each district, five officials are charged with the task of uploading data and information to the website. Meanwhile, as regards event information, the program and information subdepartment assigned three officials who work in collaboration with Ministry of Communication and Information (Kominfo), and Microsoft Indonesia, to develop some egovernment applications. Figure 2 shows the "Jogja Istimewa" website. 
It must be noted that the name of the website may be important but what is even more important to website visitors (prospective tourists and other parties with interest in tourism activities) is the content hosted on it. Thus, by implication, effective e-government development for tourism activities, relies on the relevancy, quality, accessibility, and communication strategy used to deliver website content. Website visitors do not stay long on websites that have poor quality, outdated, or poorly developed content.

Based on observation of content on DIY tourism department website, there is no doubt that the website contains content on tourist attractions in many destinations $n$ DIY. Most notable of that is information on it's the region's rich history and culture, making it a big lure of visitors compared to websites of other tourist areas. The composition of tourists who pay visits to DIY website include local, regional, national and international Meanwhile, as regards communicating tourism content, DIY Tourism Department uses various media that include websites, social media, and forums in other virtual space media.

Nonetheless, the main website for $D I Y$ tourism is www.visitingjogja.com, which is English. Using English as a medium is aimed at protecting the vision as well as based on the experience that a good percentage of tourisms to DIY are foreigners. Nonetheless, the content that consists of events, accommodation, to tourism arrangements such as package tourist attractions such as nature, beaches, history, culture, museums and tours with special interests.

Thus, e-government development by the tourism department is integrated with the marketing and destination information, which is in line with recommendations of the key components and elements of tourism as proposed by Burhan Bungin (2015). Those who want to pay visit to the physical address of DIY marketing division, can go to DIY Tourism Department offices and Tourism Information Center (TIC) on Malioboro street.

"TIC provides information on tourist destinations, favorite souvenirs of each destination, travel agent information and various events held in DIY. The integrated marketing process is also related to advertisement, which is presented in several media such as Lion Mags, Kabare, Express Air, Garuda, and airport television. Advertising is also done by publishing an event calendar once a year. Branding is an important part of the tourism communication. Over the recent past, tourism marketing has been championing the use of the slogan "Jogja Istimewa" through on air media and events". (Interview with Fitria Wahyuni, Market analysts, marketing and destinations department, 7/9/2017)

Advertising is an important component of DIY Tourism department marketing strategy. Various media are used indoors and outdoors, involving travel agents, who often have exhibition and tourist packages for tourists paying visits to certain destinations highlighting best time to make visits. Some of the tactics used to increase the number of tourists is by leveraging endorsements by public figures who make testimonials that serve as evidence of the uniqueness and value of such attractions.

In addition, the marketing department has also used social media as a marketing medium of tourism attractions. Social media such as Twitter, Instagram, Facebook and linked-in that belong to tourist destination sites are linked to district or city government tourism websites. In addition, websites statistics that include the number of tourists paying visits to various tourist attractions, tourist spending, and length of stay, which are good inputs for minoring and evaluation of the effectiveness of e-government development of DIY Tourism department. Based on websites, it became evident that Wisma tourists, tourism spending averages Rp.8 million per day, while domestic tourists spend an average of Rp.1.8 million per day. It is also important to note, that based on statistics, it is evident that the distribution of tourists visits to DIY is not evenly spread among the five districts in the region, with the Yogyakarta city, having the largest number. To that end, with respect to the distribution of tourists in the five districts, there is need for more effort by e-government to reduce the disparity in tourism spending in DIY, by for instance increasing the intensity of tourism marketing and advertising efforts.

\section{CONCLUSION}

Based on the analysis and discussion, 
several conclusions can be drawn. First, bureaucracy involved in e-government implementation in DIY Tourism Department does not have sufficient expertise in, which undermines e-government performance. Consequently, the department has to spend money on technical staff that is hired to tackle IT and other e-government related problems that arise.

Secondly, IT infrastructure is based on the Ministry of Communications and Information (Kominfo) domain, and hardware provided by DIY Tourism Department. While e-government has sufficient PCs and servers, it faces shortage of manpower with appropriate expertise. Meanwhile, as regards e-government development financing, egovernment development draws from several sources including the special status fund, APBN and APBD. Financing is integrated into marketing, advertising, and destination publicity activities conducted by the relevant divisions of the DIY Tourism department. Thirdly, one of the key components of egovernment development is content development and deployment. Content development involves third parties that include bloggers, tourism industry communities, event organizers on one hand, and collaboration with five districts that comprise DIY province. The role of the Ministry of Communication and Information is also pivotal to the development of mobile applications that are used on "Jogja Istimewa", which is accessed anytime from anywhere.

Fourthly, one of the most recent developments in tourism e-government development is $w w w$.visitingjogja.com website, which features information about events, accommodation, nature tourism destinations that include beaches and mountains; history, culture, museums and other $\mathrm{h}$ special events and festivals in $D I Y$. Results of this research have certain limitations that include its focus on local government institutions in general and local government (DIY province in particular). Moreover, the research focused on e-government implementation from the perspectives of human resources, funding, infrastructure and information resources as used and utilized by during tourism communication activities undertaken by DIY Tourism Department. Implication of this research are in the importance of adopting good governance and organizational management, which are shown to be pivotal to effective e-government development. Some of the policy recommendations include the need to strengthen human resource capacity through recruitment of employees who are graduates of computer science. Fifthly, the bureaucracy structure should not be part of the secretariat, rather a separate division of DIY Tourism Department. Creating a separate division will ensure that program and information division has sufficient duties and authority to conduct its activities, including forging collaborations with internal and external parties in egovernment development to support tourism development.

\section{REFERENCES}

Aidi, R. (2015). Penerapan Electronic Government Dalam Pelayanan Publik di Dinas Kebudayaan dan Pariwisata Provinsi Kalimanta Timur. FISIP UN$M U L, 3(1), 242-258$. Retrieved from http://ejournal.an.fisip-unmul.ac.id/ site $/ ? \mathrm{p}=1442$

Aprilia, S., Wijaya, A., \& Suryadi. (2014). Efektivitas Website sebagai Media EGovernment dalam Meningkatkan Pelayanan Elektronik Pemerintah Daerah (Studi Pada Website Pemerintah Daerah Kabupaten Jombang). WACANA, 17(2), 126-135. Retrieved from http:// wacana.ub.ac.id/index.php/wacana/ article/view/313

Basofi, S. (2015). Implementasi Kebijakan Penerimaan Peserta Didik Baru (PPDB) Online Tingkat Sekolah Menengah Atas di Kota Pekanbaru 2011-2013. JOMFSIP, 2(1), 1-15. Retrieved from https://jom.unri.ac.id/index.php/ JOMFSIP/article/download/5052/4933

Bungin, B. (2015). Komunikasi Pariwisata, Pemasaran dan Brand Destinasi. Jakarta: Prenadamedia Group.

Norman, D., \& Yvonna, L. (2000). Handbook of Qualitative Research. California: Sage Publications.

DIY, P. (2016). No Title. Retrieved March 7, 2017, from https://play.google.com/ store/apps/details? $\mathrm{id}=\mathrm{id}$.go.jogjaprov.jogjaistimewa 
Rosalia Prismarini Nurdiarti, Didik Haryadi Santoso — Communication and E-Government: The Case Study...

Mrf. (2016, September 10). Perkembangan Jumlah Wisatawan Mancanegara ke DIY Tertinggi Se-Indonesia. Retrieved from http:// jogja.tribunnews.com/2016/09/10/ perkembangan-jumlah-wisatawanmancanegara-ke-diy-tertinggi-seindonesia

Pariwisata, L. D. (2016, January 10). Annual Report. Retrieved from https:// visitingjogja.com/7670/lakip-dinaspariwisata-2015-1kjip/

Roni, H. (2015, June 3). Pengembangan EGovernment di DIY. Retrieved from http://dislautkan.jogjaprov.go.id/web/ detail/33/pengembangan_egovernment_di_diy
Wiloso, S., \& Sasongko. (2017). Evaluation of the Implementation of Tourism Policy. JKAP, 1(21), 82-104. Retrieved from https://journal.ugm.ac.id/jkap/ article/view/16751/18769

Wirawan, K. (2017, May 16). Jogja Menuju Cyber Province. Retrieved from https:// www.gudeg.net/read/9900/jogjamenuju-cyber-province.html

Yin Robert. (2012). Studi Kasus Desain \& Metode (Designs and Methods of Study Case). Jakarta: Raja Grafindo Persada. 